\title{
o-アルサニール酸の電解製 造*
}

\section{Electrolytic Preparation of o-Arsanilic Acid}

安河内一夫均, 武藤博**

Kazuo Yasukouchi, Hiroshi MUtō

\section{1 緒言}

$o$-ニトロベンゼンアルソン覆から，o-アルサニール酸 への工業的還元注現在化学的な方法が用いられ，アルカ リ性で塩化第一鉄を触媒として行なわれている(1),2)。乙 かしゲル状の沈殿として水酸化鉄が副生するために，口 過に時間がかかるという久点がある。

また電解による還元では，N-酢酸ナトリウム溶液中 で，白金陰極を用い，oーアルサニール酸を収得したとい ら報告 ${ }^{3)}$ があるが，この場合の主生成物はヒドラゾ化合 物であって，o-アルサニール酸の得量は微量であった.

そこで著者らは 0 アルサニール酸の收率の向上を目 的として，o-ニトロベンゼンアルソン酸のニトロ基の還 元を定電流電解法によって試みた。

ニトロ基をアミノ基にまで電解還元するには，一般に 酸性溶媒が用いられているが，酸性で還元するとアルソ ノ基が同時に還元される可能性も大きくなり，しかも原 料が難溶性になるという久点がある。ただ酸性溶媒中で も $\mathrm{Pt}, \mathrm{Ni}, \mathrm{Cu}$ などの低過電圧電極を使用すればアルソ ノ基は還元されないことが認められている゙．しかし， 著者らの予倩実験の結果では， $\mathrm{Cu}$ 陰極を用いた場合， アルソノ基の還元む起こらなかったが同時にニトロ基す アミノ基まで澴元されなかった。

そこでまず原料が易溶で，しかもアルソノ基の還元を おさえ，ニト口基をアミノ基にまで還元するような電解 液执よび電極を検討することとした。

1）アルカリ性では，アルソノ基の還元は行なわれな $\left({ }^{5}\right)$.

2）ニトロベンゼンをアルカリ性で還元した場合は主 として，アゾオキシ，アゾあるいはヒドラゾ化合物など が得られる(6),7)。しかし触媒として銅粉を用いると電流 効率がほとんど $100 \%$ でアニリンにまで還元される8 .

3）触媒としては，重金属塩または金属粉末があげら れている97 11)

しかしアルカリ性で金属塩類を用いると水酸化物が生 成しやすいので，アルカリに不溶な金属粉として， $\mathrm{Cu}$ ， $\mathrm{Fe}, \mathrm{Ni}, \mathrm{Pb}$ などを利用することが考えられる。

以上の事実を考慮して予供実験を行なった結果，アル

* 昭和 41 年 4 月 5 日電気化学協会第 33 回大会発表

** 熊本大学㩰学部菜品製造工学教宝 (熊本市大江町九品寺)
カリ性において銅陰極および銅粉触媒を使用した場合に のみ ニール酸の収量を向上させるための電解条件の因子とし て, 電流密度, 電解温度, 触媒量, アルカリ濃度を定め 実験計画法によってその相関関係を求め，それらの結果 からさらに個々の因子の量的な検討を行ない，比較的好 収量を以て

\section{2 実験および結果}

\section{1 実験 装置}

実験は図 1 に示すような装置を用いて行なった。

1）陰陽雨極液は素 焼円筒製隔膜で分割し 陽極には円筒状金属, 陰極にはコイル状に巻 いた金属パイプ（有効 表面積約 $210 \mathrm{~cm}^{2}$ ) 范 使用し，マグネチック スターラーによって陰 極液を汃くはんした。

2) 陰極液には，電 解直前に窒素ガスを約

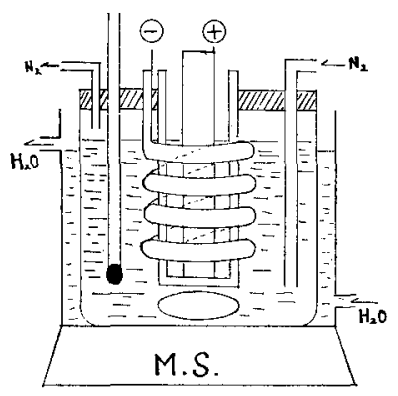

図 1 電解装置 30 分間通じてできるだけ 溶存酸素を除去し, 電解中も 窒素ガスの導入を続行した。また電解中の温度は恒温水 の循環によって各設定温度に保った。

3）定電流電源としては柳本製作所製定電位電解装置 を使用した。

\section{2 予 備 実 験}

2.2.1 酸性電解液における還元 前記のようにアル ソノ基は酸性溶媒中で低過電生電極を使用すれば還元さ れないことが知られている4)ので，硫酸及性電解液で銅 陰極を用い，表 1-1に示すよ5な条件で電解還元を行な った. その結果陰極液中に淡黄色沈殿 (A) が析出し, この沈殿を口別後，口液を濃縮して橙黄色沈殿（B） 収得したここれらの沈殿（A），(B) をそれぞれ図2の 1-A 执よび B に示すような方法で検討した結果，アル ソノ基は存在するがアミノ基は存在しないことが認めら れ，(A) はアゾオキシ化合物，(B) はヒドラゾ化合物 と推定された。

2.2.2 アルカリ電解液における還元アルカリ溶媒 
表 1 予侗実験の霄解条件および生成物

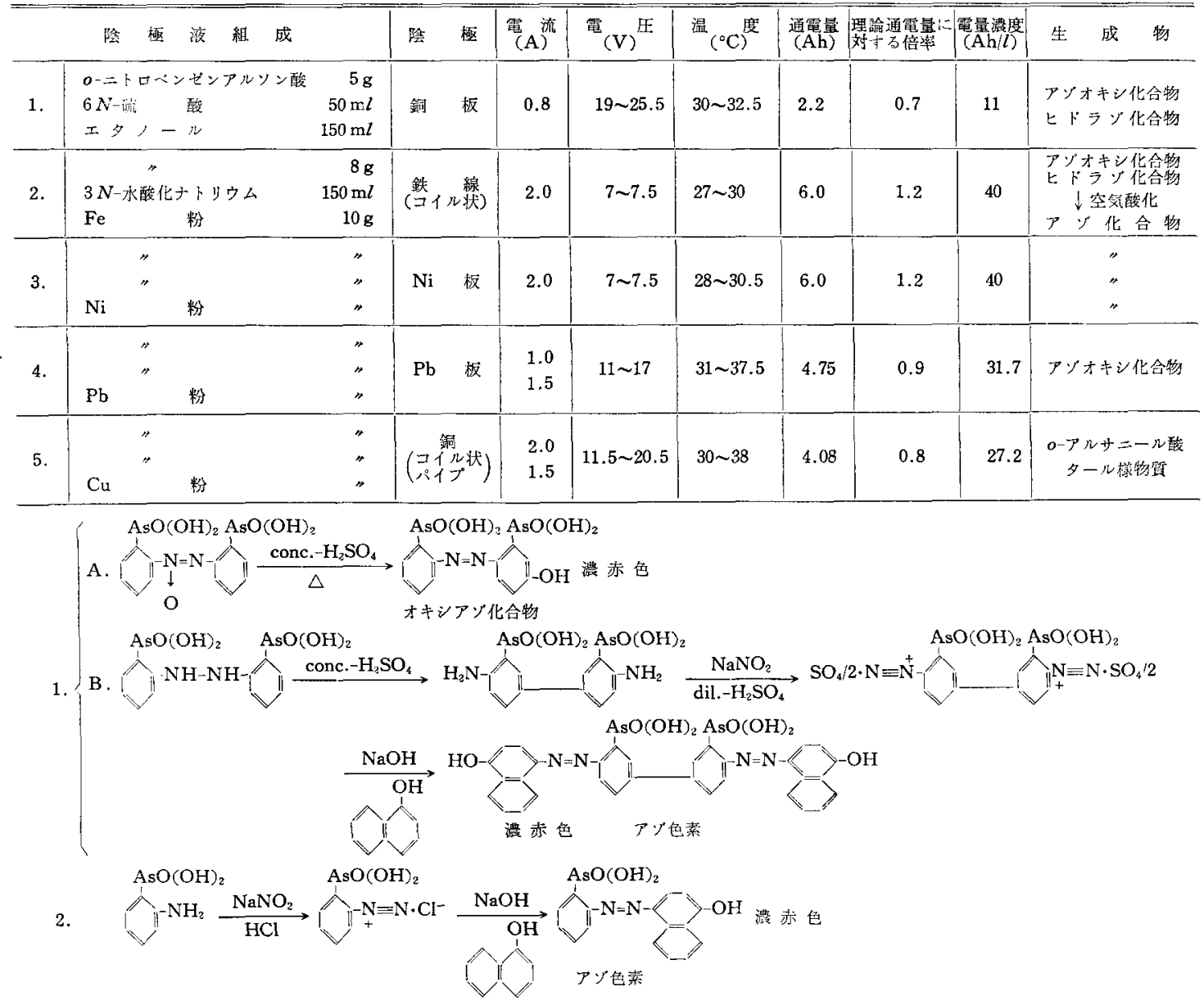

3.

図2 化学反忘による生成物の推定

中では原料が劰溶となり，しかもアルソ/基の還元は起 こらず，適当な触媒，電極を用いれば，ニトロ基をアミ ノ樭まで還元することが可能であると考えた。そこで陰 極および添加触媒として $\mathrm{Fe}, \mathrm{Ni}, \mathrm{Pb}, \mathrm{Cu}$ などの 4 種の 金属板および金属粉壳利用して，表102〜5に示すよ らな条件で還元を行ない，それぞれ生成物を検討した。 その結果，表 1 に示すように，o-アルサニール酸が生成 したのは銅極，銅粉触媒を用いた場合のみであった。

\subsection{3 電解終了夜の処理}

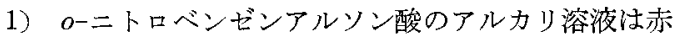

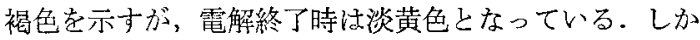
しこの液を口過し金属銅の分離操作中に口液の色は再び 赤褐色に変化した. 分離した液を $40 \sim 50^{\circ} \mathrm{C}$ でロータリ 一エバポレーターを用いて $1 / 4$ 量位まで減圧濃縮すると 溶液はさらに黒褐色に変化した．この液を水で冷却しつ
つ濃塩酸で中和すると, 食塩が析出するとともにメチル オレンヂの変色点近くで黒色の夕一ル状物が析出し, 溶 液は赤褐色となった。これを口過しタール状物を口別 後, 口液にさらに塩酸を加え $\mathrm{pH} 2.2$ まで酸性にして冷 却すると

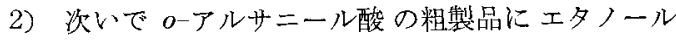
を加えて食塩を除去した後, 水溶液から3回再結晶を行 なった。

3）タール状物質はアルサニール酸の生成と関係があ り,タール状物が析出しないときはアルサニール酸も生 成しないことが忍められた。タール状物質は酸, アルカ リに易溶で，ベンゼン，アセトン，エーテル，四塩化炎 素，クロロホルムなどに不溶であった。黒色タール状物 質を無水エタノールで抽出し，食塩を分離後濃縮すると 黄色の沈殿が析出するが，エタノールを完全に除くと再 


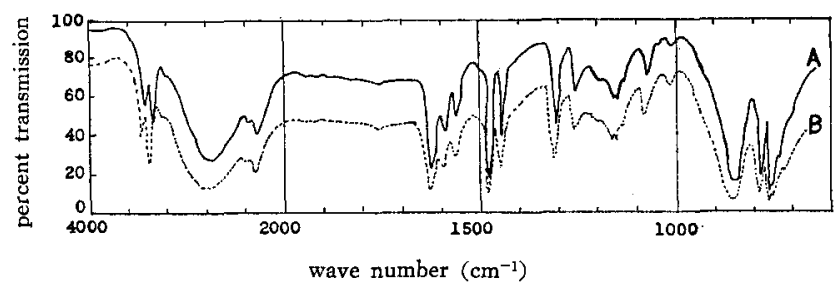

A : 既知物澌 B : 電解生成物

図3 赤外線吸收スペクトルによる生成物の同定

び黄褐色タール状物質となった。これに少量の水を加え ると, 再び沈殿が析出し，o-アルサニール酸を分離する ことができたが，やはりタール状物質が残る。このタ一 ル状物質については現在検討中である。

\section{2 .4 o-アルサニール酸の確認}

1) アミノ基：図 2-2 に示すように生成物を希塩酸打 よび亜硝酸ナトリウムでジアゾ化した後， アルカリ溶液を加えると濃赤色のアゾ色素を生成し，ア ミノ基の存在を確認した.

2）アルソノ基：i）生成物に炭酸水素ナトリウムを 加えると図 2-3 に示すよらに炭酸ガスを発生した．ii) 生成物の水溶液に N/10-ヨウ素溶液を加えてもヨウ素を 消費しなかった，以上の結果から，アルソノ基の確認を 行なった。

3）融点： $153^{\circ} \mathrm{C}$, 純品との混融試験によっても融点 降下が認められなかった。

4）赤外線吸収スペクトル

上記の電解生成物と同仁薬化製の純品との IR スペク トルは図 3 に示すように全吸収带で一致した。

2.2.5 実験計画法による条件の決定 予備実験とし て銅極，銅粉触媒を用いアルカリ性溶媒で電解した場合 のみのーアルサニール酸が生成することがわかったので 実験計画法に基づいて，表 2 に示すよらな各因子，水準 を決め 16 個の実験を行なった。各実験例とも前述と同 様な電解終了液の処理を行ない，得られた結晶を融点お 表 2 実験計画法の因子杼よび水準

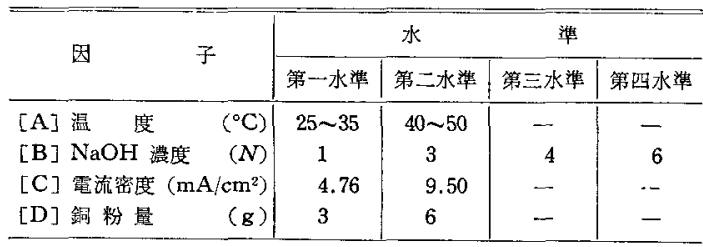

表 3 実験計画法の解析結果

\begin{tabular}{|c|c|c|c|c|c|c|}
\hline \multirow{2}{*}{ 因 } & \multirow{2}{*}{$\begin{array}{c}\text { 二案和 } \\
(S)\end{array}$} & \multirow{2}{*}{$\begin{array}{c}\text { 目由度 } \\
(\phi)\end{array}$} & \multirow{2}{*}{$\begin{array}{c}\text { 不 偏 } \\
\text { 分 政 } \\
(V)\end{array}$} & \multirow{2}{*}{$\begin{array}{c}\text { 分散比 } \\
\left(F_{0}\right)\end{array}$} & \multicolumn{2}{|c|}{ 危 除 率 } \\
\hline & & & & & $F(0,01)$ & $F(0.05)$ \\
\hline [B] $\mathrm{NaOH}$ 涉度 & 2.54 & 3 & 0.85 & $5.30^{*}$ & 6.55 & 3.71 \\
\hline [C] 電 流密 度 & 0.28 & 1 & 0.28 & 1.73 & 10.04 & 4.96 \\
\hline [D] 銅 粉 量 & 0.68 & 1 & 0.68 & 4.26 & 10.04 & 4.96 \\
\hline$e^{\prime}$ & 1.60 & 10 & 0.16 & - & - & - \\
\hline
\end{tabular}

$e^{\prime}:[\mathrm{A}]$ 温度をプールした䛃差
よび赤外吸収スペクトルで同定した後, 得量を 算出した。この 16 個の害戨の解析結果は，表 3 の示すように，温度，電流密度，銅粉の量な どの因子の水準間に澺差がなく，経済性， 作業性を考慮に入れて都合の良い水準をとれば 良いが，水酸化ナトリウムの濃度に対してのみ 危険率 $5 \%$ で有意差があることが認められた。 また，水酸化ナトリウムの濃度による収量の平 均值は，表 4 に示すように $3 N$-水酸化ナ卜リ

表 4 水酸化ナトリウムの濃度による平均収量の变化

\begin{tabular}{l|c|c|c|c|c}
\hline $\mathrm{NaOH}$ & \\
\hline \multirow{2}{*}{ 濃度 } & $(N)$ & 1 & 3 & 4 & 6 \\
\hline \multirow{2}{*}{ 量 } & $(\mathrm{g})$ & 0.85 & 1.18 & 1.13 & 0.18 \\
& $(\%)$ & 17 & 24 & 23 & 4 \\
\hline
\end{tabular}

ウムの場合が最も良いことを示している。

2.2.6 各因子の量的検討 解析の結果, 水酸化小卜 リウム濃度の水淮間に有意差があることが認められたの で，これを一定にして銅粉量, 電気量などの収量に及ぼ す影響を検討した.この場合表 4 に示したように水酸化 ナトリウムの濃度が $3 N$ でも $4 N$ でもはとんど得量に 差がなく，また実験計画法による 16 個の実䮖のうち特 に収量の良かったの注 $4 N$ の場含であったので，以後 $4 N$-水酸化ナトリウム溶液中で電解逻儿を行なった。

1）触媒の量 触媒として使用寸る銅粉は前記の 16 個の実験条件の $6 \mathrm{~g}, 3 \mathrm{~g}$ いずれの場合も，電解中かきま ぜが完全に行なわれず電解ソウの底部に沈殿している量 が多く，また，銅粉が何度も使用可能なことから，銅粉 の量による収量の変化を検討した。この場合使用する銅 粉の量を支配する因子は銅粉自体の触媒能以外に，電解 ソウ，電極の構造およびかきまぜの方法などがあげられ る.

そこで，表 5-1 に示すよ5な条件で銅粉の量を変化さ せて電解した．その結果，銅粉の量が $3 \mathrm{~g}$ 以下になると 収率は半分以下に低下した。しかし，触媒の量は電解ソ ウ，陰標の構造およびかきまぜの方法などの改善によっ て電解液との接触を多く寸ることが可能であるからさら に銅粉の量を少なくできると考えられる。

2）電気量 他の電解条件を一定にして霄気量だけを 変化させ, 表 5-2に示すような条件で電解を行なった。 その結果，通電量 $4.0 \mathrm{Ah}$ (理論通電量の 123\%) の場 合の收率が最も良く，通電量 4.0 および $5.0 \mathrm{Ah}$ で電 解した陰極液に塩酸を添加する際には，タール状物が副 生するが， $3.5 \mathrm{Ah}$ 以下で電解した場合には副生しなか った.

3) 電流密度 他の条件を一定にして電流密度だを 変化させ, 表 5-3に示すような条件で電解を行なった. その結果, $4.76 \mathrm{~mA} / \mathrm{cm}^{2}$ の場合の得量が最も良かった。

4) 原料の純度 タール状副生物の生成原因竞検討す 
表 5 各因子の量的検討の実験結果

陰極液䋎成 : $ロ$-二トロベンせンアルンン酸 $5 \mathrm{~g}$ $4 N-\mathrm{NaOH}$ 溶液 $120 \mathrm{ml}$

\begin{tabular}{|c|c|c|c|c|c|c|c|c|}
\hline & 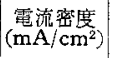 & 電 $(\mathrm{V})$ & $\mid$ & $\frac{1 \text { 銅粉量 }}{(\mathbf{g})}$ & 原料の純度 & $\mid$\begin{tabular}{|l|} 
収量 \\
$(\mathbf{g})$
\end{tabular} & $\begin{array}{l}\text { 双率 } \\
(\%)\end{array}$ & 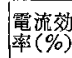 \\
\hline $\begin{array}{l}1 . \\
\text { 触 } \\
\text { 媒 } \\
\text { 量 }\end{array}$ & 9.5 & $7 \sim 9$ & 4.0 & $\begin{array}{l}6 \\
3 \\
2 \\
1\end{array}$ & 粗 製 品 & $\begin{array}{l}2 \\
2 \\
1 \\
0.4\end{array}$ & $\begin{array}{r}45 \\
45 \\
23 \\
9\end{array}$ & $\begin{array}{r}37 \\
37 \\
18 \\
7\end{array}$ \\
\hline \begin{tabular}{c|}
2. \\
電 \\
気 \\
量
\end{tabular} & 4.76 & $4 \sim 5$ & $\begin{array}{l}3.24 \\
3.5 \\
4.0 \\
5.0\end{array}$ & 3 & 粗 慗 品 & $\begin{array}{l}0.32 \\
0.18 \\
2.0 \\
1.9\end{array}$ & $\begin{array}{r}7 \\
4 \\
45 \\
43\end{array}$ & $\begin{array}{r}7 \\
4 \\
37 \\
28\end{array}$ \\
\hline $\begin{array}{l}3 . \\
\text { 篭 } \\
\text { 流 } \\
\text { 度 }\end{array}$ & $\begin{array}{c}4.76 \\
9.5 \\
16.5 \\
22.2\end{array}$ & $4 \sim 7.8$ & 4.0 & 3 & 再結晶二回 & $\left|\begin{array}{r}2.5 \\
2.0 \\
0.5 \\
\text { 徽量 }\end{array}\right|$ & $\begin{array}{l}57 \\
45 \\
11 \\
-\end{array}$ & $\begin{array}{r}46 \\
37 \\
9 \\
-\end{array}$ \\
\hline $\begin{array}{l}4 . \\
\text { 原純 } \\
\text { 料放 } \\
0\end{array}$ & 4.76 & $4 \sim 5$ & 4.0 & 3 & $\begin{aligned} & \text { 粗 製 } \text { 品 } \\
& \text { 再結晶一回 } \\
&=\text { 二回 }\end{aligned}$ & $\begin{array}{l}2.0 \\
2.2 \\
2.5\end{array}$ & $\begin{array}{l}45 \\
50 \\
57\end{array}$ & $\begin{array}{l}37 \\
41 \\
46\end{array}$ \\
\hline
\end{tabular}

るために原料の純度について検討した，粗製品を水から 辑結晶したものと比較するために表 5-4 に示すような条 件で電解を行なった，その結果原料の純度をあげると当 然生成物の得量は良くなる。しかしタール状物質の生成 量にはほとんど影響なく，タール状物が副生する原因が 不純物にあるのではなく，O-ニトロベンゼンアルソン酸 自身であることを諗めた。

\section{3 総括}

1) 銅粉を触媒として電極に銅を使用すれば，アルカ リ溶液中での によって

2) 電解条件としては，常温において，3N-水酸化广
トリウム, $123 \%$ の通電量, $4.76 \mathrm{~mA} / \mathrm{cm}^{2}$ の電流密度が 最む適当であるとみなされた。

3）電解による収量の最高は約 $57 \%$ で化学的方法の 約 $60 \%$ にやや劣るが，取り扱った原料が少量であるこ とおよび操作時間の短縮を考慮するとともに，化学的方 法の場合より純粋な生成物が得られることなどからも， 十分大量化の可能性がある.

4） $5 \mathrm{~g}$ の原料に対して $3 \mathrm{~g}$ の触媒が必要であるが, 電解ソウ, 電極の構造, かきをぜの方法を改良すれば触 媒量を少なくし，収量を増加させる可能性がある.

5）電解液の循環的使用の可能性は小さいが，電極お よび触媒の反覆使用は可能である.

6）タール状物質生成の原因は原料自体あるいは還元 の中間体にあると考えられるが，その確認は還元機構に 関連するので現在検討中である。

終りに, 本研究に当たって,ご指導をいただいた本学占部則 明教授および原料と研究費の一部它提供下さった同仁薬化学研 究所に深謝致します。また，IR スペクトルの測定をして頂いた 本学中央分析室の田中紀子氏に感謝致します.

(昭 41-9-6 受理)

\section{文献}

1) J.R. Johnson, R. Adams, Am. Soc. 45, 1312 (1923).

2) W.A. Jacobs, M. Heidelberger, I.P. Rolf, J. Am. Chem. Soc. 40, 1580 (1918).

3) F. Fichter, E. Elkind, B. 49, 246 (1916).

4) K. Matsumiya, H. Nakata, Mem. Coll. Sci., Kyoto [A] 12, 63 (1928).

5) F. Fichter, E. Elkind, B. 49, 240 (1916).

6) 関根太郎, 日化 77,68 (1956).

7) 関根太郎, 工化 60, 918 (1957)

8) C.F. Boehringer, Söhne, D.R.Pat. 130742, 131404 (1902),

9) C.F. Boehringer, D.R.Pat. 116942, 117007 (1900).

10) K. Elbs, F. Silbermann, Z. Elektrochem. 7, 589 (1901).

11) D.A. Chilesotti Z. Elektrochem. 7, 768 (1901).

\section{多孔質炭素電極 の研 究* \\ 一フッ素樹脂薄膜による電極の防水一}

\section{Studies on the Porous Carbon Gas Electrodes}

\section{Wetproofing of Porous Carbon Electrodes with Polytetrafluoroethylene Film}

\author{
藤 井 禄 郎**, 三 宅 義 造** \\ Rokuro FujII, Yoshizo MiYake
}

\section{1 緒言}

ガス電池の電極には多孔質で表面積の大きい電気伝導 性材料が要求される。直径 $10^{-7} \sim 10^{-4} \mathrm{~cm}$ の細孔と 300 $\sim 800 \mathrm{~m}^{2} / \mathrm{g}$ の表面積をもっている多孔質炭素は，現在

\footnotetext{
* 昭和 41 年 4 月 5 日電気化学協会第 33 回大会化て発表
}

**大阪工業技術試験所（大阪书大淀区大淀町北一丁目）
ガス電池用電極として，もっとも適当な材料と考えられ ている゙、しかし，このものは電解液沈れやすい表面 状態と，毛管現象をおこしやすい構造をもっているので 電極として使用するには，電解液の極内浸透を阻止する ための防水処理が必要である。

多孔質炭素電極の防水処理は，一般にポリエチレン， ポリスチレン, パラフィンワックスなどを有機溶剤に溶 